\title{
Optimization of RSW parameters by joining galvanized steel HZ 220 BD-Z100 MB with aluminium AV 1050A
}

\author{
P. Sejč* ${ }^{*}$ Z. Gábrišová \\ Institute of Technologies and Materials, Faculty of Mechanical Engineering, Slovak University of Technology, \\ Pionierska 15, 83102 Bratislava, Slovak Republic
}

Received 21 January 2018, received in revised form 6 April 2018, accepted 24 April 2018

\begin{abstract}
The main trend in the automotive industry today is the reduction in vehicle weight. The problem is addressed first and foremost by the use of different types of light and high strength materials in the production of the car body. Although galvanized steel sheet is still the basic construction material, nowadays aluminium alloy sheets are increasingly used in the production of vehicles. This paper is focused on the optimization of process parameters by resistance spot welding dissimilar materials: galvanized steel sheet and sheet made of aluminium.
\end{abstract}

K e y w or d s: resistance spot welding, steel/aluminium joints, weld nugget, properties

\section{Introduction}

There are several options for making joints between steel and aluminium: screwing, bonding, and joints obtained by welding [1]. Welding methods in practice have been mainly applied by technologies using concentrated energy sources - laser beam [2-4], and to a limited extent also TIG and MIG arc welding technologies $[3,5]$.

The most commonly used process for joining thin steel sheets for a car body is resistance spot welding.

The problems of metallurgical bonding of different metallic materials depend on their weldability and different physical properties: melting temperatures, thermal and electrical conductivity, and thermal expansion. The properties of the welded joint are fundamentally affected by the chemical composition of the melt pool.

Aluminium materials are coated on the surface with an impermeable oxide layer which causes considerable problems when welding these materials. The oxide layer is compact throughout the surface of the material. It does not dissolve in the molten metal and worsens weld formation. It is electrically nonconductive and has a melting temperature of $2050^{\circ} \mathrm{C}$, thereby aggravating the conditions for local melting. For these reasons, it is necessary to remove the ox- ide layer from the surface of the material shortly before welding and to prevent its formation during welding. In the preparation of joints, the layer is removed mechanically or chemically. Aluminium has low electrical resistivity and high thermal conductivity (Table 1), which influences the choice of a suitable heat source. In aluminium and its alloys, the solubility of gases, especially hydrogen, decreases significantly during the solidification of the molten metal, resulting in the porosity of the welds. Selected types of aluminium alloys are additionally susceptible to hot cracking [6].

Zinc coating on steel sheets provides the material with resistance to atmospheric corrosion. However, it has a negative impact on weldability. Zinc has considerably lower electrical resistance than low-carbon unalloyed steel (Table 1). Also, the melting temperature of zinc $\left(419^{\circ} \mathrm{C}\right)$, Table 1 , as well as its evaporation temperature $\left(907^{\circ} \mathrm{C}\right)$ are significantly lower than the melting point of $\mathrm{Fe}\left(1538^{\circ} \mathrm{C}\right)$. When galvanized steel sheet is melted, $\mathrm{Zn}$ evaporates, which may cause microstructural defects (e.g., pores) [7]. The creation of a metallurgical joint between steel and aluminium requires, in the first place, a detailed understanding of the properties of the materials. Problems with fusion welding are caused mainly by a different melting point $\left(660^{\circ} \mathrm{C}\right.$ for $\mathrm{Al}$ and $1537^{\circ} \mathrm{C}$ for $\left.\mathrm{Fe}\right)$, almost zero iron solubility in aluminium and formation of brittle

*Corresponding author: e-mail address: pavol.sejc@stuba.sk 
Table 1. Selected properties of metals used

\begin{tabular}{lccc}
\hline & $\mathrm{Al}$ & $\mathrm{Fe}$ & $\mathrm{Zn}$ \\
\hline Density, $\rho\left(\mathrm{kg} \mathrm{dm}^{-3}\right)$ & 2.7 & 7.874 & 7.14 \\
Melting point, $T\left({ }^{\circ} \mathrm{C}\right)$ & 660 & 1537 & 419 \\
Electrical resistivity, $\rho(\Omega \mathrm{m})$ & 28.2 & 96.1 & 59 \\
Thermal conductivity, $\lambda\left(\mathrm{W} \mathrm{m}^{-1} \mathrm{~K}^{-1}\right)$ & 237 & 80.4 & 116 \\
Thermal expansion, $\alpha\left(10^{-6} \mathrm{~K}^{-1}\right)$ & 23.1 & 11.8 & 30.2 \\
\hline
\end{tabular}

Table 2. The chemical composition of HX 220 BD - Z100 MBO steel (wt.\%) [11]

\begin{tabular}{cccccccc}
\hline $\mathrm{C}$ & $\mathrm{Si}$ & $\mathrm{Mn}$ & $\mathrm{P}$ & $\mathrm{S}$ & $\mathrm{Nb}$ & $\mathrm{Ti}$ \\
\hline 0.1 & 0.5 & 0.7 & 0.06 & 0.025 & 0.09 & 0.12 \\
\hline
\end{tabular}

Ta ble 3. Selected mechanical properties of experimental materials [11-14]

\begin{tabular}{lcc}
\hline Material & HX220BD+Z & AW 1050A \\
\hline Yield strength, $R_{\mathrm{P} 0.2}(\mathrm{MPa})$ & $220-280$ & $75-85$ \\
Tensile strength, $R_{\mathrm{m}}(\mathrm{MPa})$ & $320-400$ & $105-145$ \\
Elongation, $A_{80}\left(* A_{50}\right)(\%)$ & 32 & $20^{*}$ \\
Thermal conductivity, $\lambda\left(\mathrm{W} \mathrm{m}^{-1} \mathrm{~K}^{-1}\right)$ & $46^{* *}$ & 229 \\
Electrical conductivity $\left(\mathrm{S} \mathrm{m}^{-1}\right)$ & $5.9 \times 10^{6}$ & $36.9 \times 10^{6}$ \\
\hline
\end{tabular}

** for steels with $\mathrm{C}<0.5 \%$

Table 4. The chemical composition of zinc coating (wt.\%)

\begin{tabular}{ccc}
\hline $\mathrm{O}$ & $\mathrm{Al}$ & $\mathrm{Zn}$ \\
\hline 1.63 & 1.18 & 97.19 \\
\hline
\end{tabular}

intermetallic compounds, such as $\mathrm{Fe}_{2} \mathrm{Al}_{5}$ and $\mathrm{FeAl}_{3}$ [8-10].

\section{Experimental material and the methodology of experiments}

For the production of the test samples were used:

1. HX $220 \mathrm{BD}-\mathrm{Z} 100 \mathrm{MBO}$ zinc coated steel sheet, of thickness $h_{1}=0.8 \mathrm{~mm}$. Chemical composition and selected properties are shown in Tables 2 and 3 . The thickness of the $\mathrm{Zn}$ layer measured on the cross sections was $15 \mu \mathrm{m}$ in average. The chemical composition of the zinc coating was measured on the surface of the welded sheets using an electron microscope with an EDS analyzer and is shown in Table 4.

2. EN AW 1050A aluminium sheet (pure aluminium $99.5 \%$ ) of thickness $h_{2}=1.0 \mathrm{~mm}$. The chemical composition and selected properties of $\mathrm{Al}$ plates are shown in Tables 5 and 3 . On the $100 \times 30 \mathrm{~mm}^{2}$

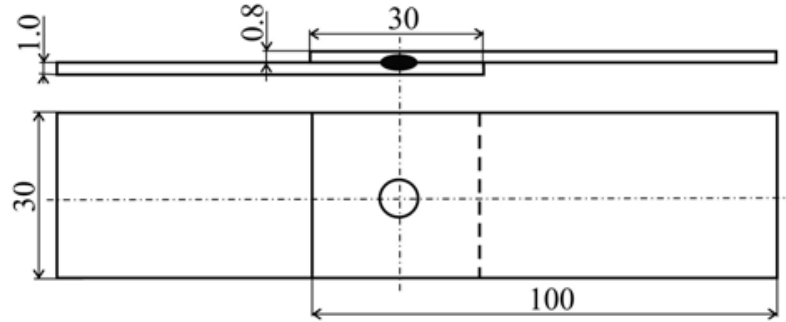

Fig. 1. Sample sizes and position at welding.

blanks, as seen in Fig. 1, lap joints were made. Welding was performed with an ARO resistance welding gun, of type XMA (XM 3612A26E52). It is a $50 \mathrm{~Hz}$ welding device with permanent power $\mathrm{SP}=26 \mathrm{kVA}$. The ULB 1.4, VTS control system was used to set and control the welding parameters. To determine the actual heat input to the weld, the measured welding parameters obtained by the Miyachi measuring device, of type Weld Checker MM-356B with accessories (current loop, voltage clamps, pressure sensor) were applied. Welding electrodes of type FB, class II made of $\mathrm{CuCrZr}$ alloy [15] were used for welding. These electrodes are recommended for welding galvanized steel sheets.

Before welding, the galvanized steel and aluminium sheets were cleaned using acetone. A steel brush with stainless steel bristles was used to remove the $\mathrm{Al}_{2} \mathrm{O}_{3}$ 
Table 5. The chemical composition of aluminium alloy AW 1050A (wt.\%) [15, 12]

\begin{tabular}{cccccccc}
\hline $\mathrm{Al}$ & $\mathrm{Cu}$ & $\mathrm{Fe}$ & $\mathrm{Mg}$ & $\mathrm{Mn}$ & $\mathrm{Si}$ & $\mathrm{Ti}$ & $\mathrm{Zn}$ \\
\hline 99.53 & 0.05 & 0.40 & 0.05 & 0.05 & 0.25 & 0.05 & 0.07 \\
\hline
\end{tabular}

Table 6. Process parameters used in the production of the test samples and the results of the peel test

\begin{tabular}{|c|c|c|c|c|c|c|}
\hline $\begin{array}{l}\text { Sample } \\
\text { number }\end{array}$ & $\begin{array}{c}\text { Welding time } \\
t_{1} \text { (per.) }\end{array}$ & $\begin{array}{c}\text { Current } \\
I(\mathrm{kA})\end{array}$ & $\begin{array}{l}\text { Voltage } \\
U(\mathrm{~V})\end{array}$ & $\begin{array}{c}\text { Heat input } \\
Q(\mathrm{~kJ})\end{array}$ & $\begin{array}{l}\text { Weld nugget diameter } \\
\qquad d(\mathrm{~mm})\end{array}$ & Peel tests results \\
\hline 1 & 5 & 8.19 & 0.86 & 0.70 & 0.00 & Non-fusion joint \\
\hline 2 & 5 & 9.68 & 0.91 & 0.88 & 3.10 & Fusion joint \\
\hline 3 & 5 & 8.95 & 0.89 & 0.77 & 0.00 & Non-fusion joint \\
\hline 4 & 5 & 10.51 & 0.96 & 1.01 & 4.40 & Fusion joint \\
\hline 5 & 5 & 11.31 & 0.98 & 1.11 & 4.80 & Fusion joint \\
\hline 6 & 5 & 12.01 & 1.00 & 1.20 & 2.60 & Fusion joint with expulsion \\
\hline 9 & 3 & 9.56 & 0.98 & 0.57 & 0.00 & Non-fusion joint \\
\hline 10 & 3 & 10.48 & 1.01 & 0.64 & 0.00 & Non-fusion joint \\
\hline 11 & 3 & 11.19 & 1.07 & 0.72 & 0.00 & Non-fusion joint \\
\hline 12 & 3 & 11.92 & 1.08 & 0.77 & 3.10 & Fusion joint \\
\hline 13 & 3 & 13.03 & 1.00 & 0.78 & 3.10 & Fusion joint \\
\hline 14 & 3 & 13.65 & 1.04 & 0.85 & 3.50 & Fusion joint with expulsion \\
\hline
\end{tabular}

oxide layer from the $\mathrm{Al}$ sheet.

The parameter optimization was a 2-step process:

1. The criterion for optimizing the welding parameters was the diameter of the weld nugget evaluated by the peel test according to EN ISO 10440. The size of the weld nugget was assessed by EN ISO 18595. Using constant welding force, the following relationship was used to calculate the minimum diameter $d_{\min }(\mathrm{mm})$ of the weld nugget, Eq. (1):

$$
d_{\min }>4 \sqrt{h}
$$

where $h(\mathrm{~mm})$ is the thickness of the welded sheet.

The low heat input (low welding current) manifested results in an insufficient diameter of the weld nugget. Conversely, excessive heat input (high welding current) results in expulsion of liquid metal from the weld and the occurrence of defects (voids, unsymmetrical weld, lack of fusion) [16].

2. The structure of the weld joint was evaluated on transverse sections prepared by conventional metallographic procedures. $3 \%$ of Nital and Keller's etchant were used to make the structure visible. The following phenomena were detected:

- the occurrence of subsurface joint defects (cracks, lack of fusion, porosity),

- influence of heat input on the range of fusion of welded materials,

- changes in chemical composition and structure in the transition zone between steel and aluminium sheets.

A light and electron microscope with an EDS analyzer was used for the analysis.

\section{Obtained results}

1. The process of optimizing the spot resistance welding parameters is documented in Table 6. The constant welding force $F=1.5 \mathrm{kN}$ was used to produce the test samples. Two series of samples were made for which welding times were used: $t_{1}=3$ per. $(0.06 \mathrm{~s})$ and $t_{2}=5$ per. $(0.10 \mathrm{~s})$. Short welding times were chosen due to the good electrical and thermal conductivity of AW 1050A aluminium material [12]. The calculation of thermal input $Q(\mathrm{~J})$ was based on the basic equation for determining the amount of heat at resistance welding, Eq. (2):

$$
Q=\int_{t=0}^{t=t_{\mathrm{S}}} I^{2}(t) R(t) d t,
$$

where $I(\mathrm{~A})$ is the welding current, $R(\Omega)$ is total resistance at welding point, and $t_{\mathrm{s}}(\mathrm{s})$ is current flow time.

Considering the use of a constant current and neglecting the change of resistance $R$ during heating, we can use the simplified and revised equation, Eq. (3):

$$
Q=I^{2} R t=U I t
$$

where $U(\mathrm{~V})$ is the voltage measured between the electrodes.

By increasing the heat input to the weld (by increasing the welding current) at welding time $t_{1}=3$ per. $(0.06 \mathrm{~s})$, the nature of the joint between the galvanized steel and the aluminium sheet changed, thus confirming the results of the peel test (Table 6). 

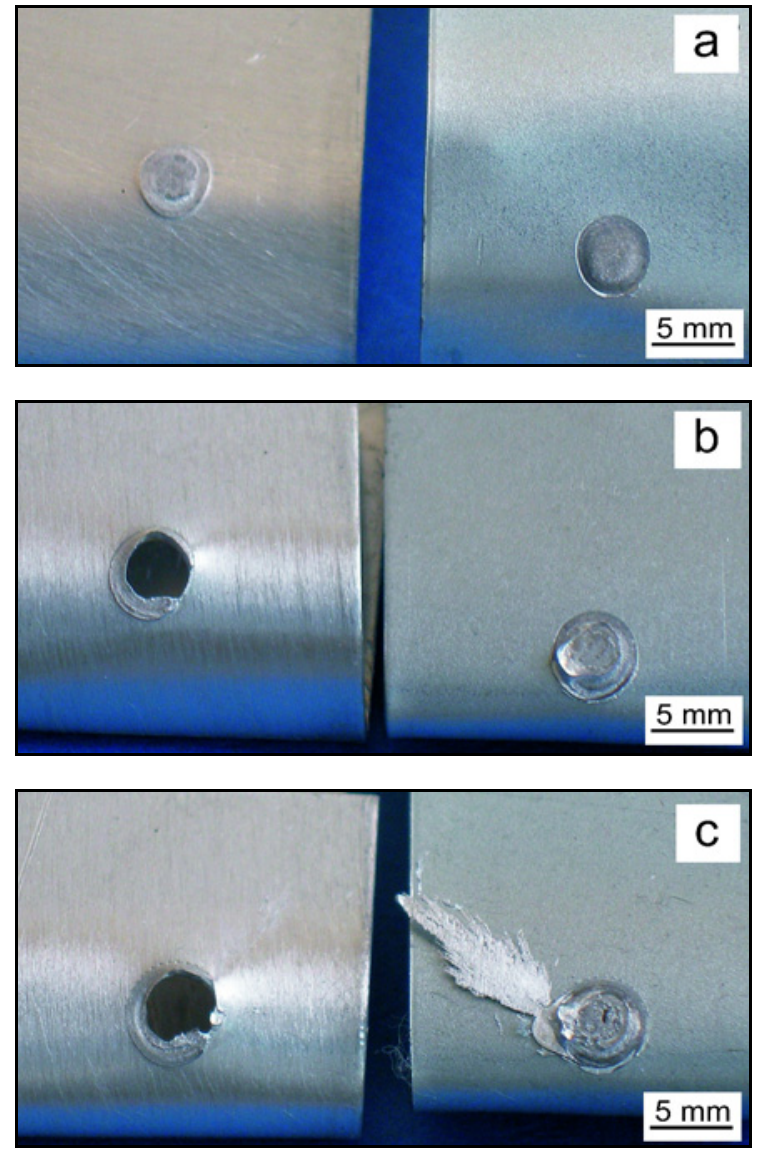

Fig. 2. Samples after peel test: (a) No. $9(Q=0.56 \mathrm{~kJ}$, $t_{1}=3$ per. $)$, (b) No. 13 ( $Q=0.78 \mathrm{~kJ}, t_{1}=3$ per. $)$, and (c) No. $14\left(Q=0.85 \mathrm{~kJ}, t_{1}=3\right.$ per. $)$.

With low welding currents $I=9.56$ to $11.19 \mathrm{kA}$ (Fig. 2a), interface defects occurred. Such joint quality obtained by resistance spot welding is unsatisfactory in terms of loading capacity. Upon increasing the welding current value above $12 \mathrm{kA}$, it was possible to produce a weld joint that was broken by the plug-in failure of a nugget on the side of Al-sheet material. The location of the joint failure results from the significantly different mechanical properties (strength) of the galvanized steel sheet HX $220 \mathrm{BD}$ and the aluminium sheet AW 1050A, Table 3 (the strength of the steel sheet is 3 times the strength of the aluminium material).

Figure 2b illustrates the sample made by current $I=13 \mathrm{kA}$ (Table 6 ) after the peel test with symmetrical tearing of the joint material. A further increase of the current above $I=13.5 \mathrm{kA}$ (Table 6, Fig. 2c) was manifested by the expulsion of molten metal at the welded sheets' interface. The creation of expulsion is generally due to the expansion of molten metal, which by its compressive effect acts against the direction of the action of the pressing force [16]. Loss of weld nugget material during expulsion is the cause of
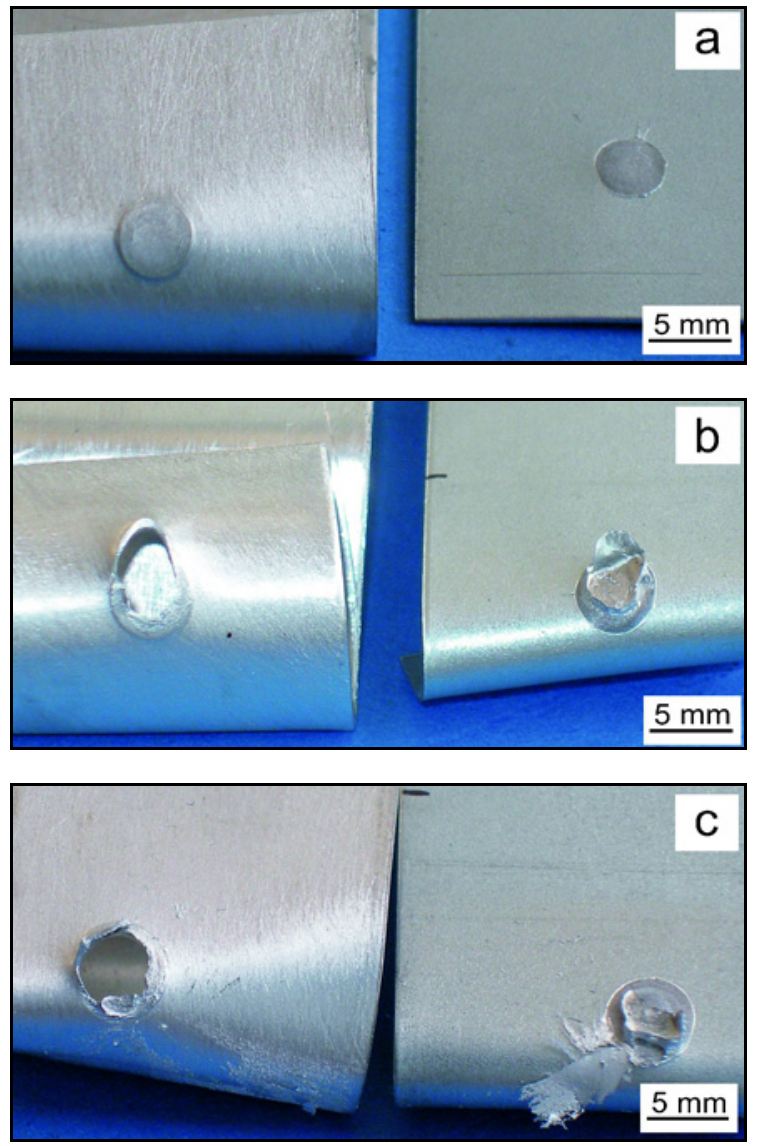

Fig. 3. Samples after peel test: (a) No. $1(Q=0.70 \mathrm{~kJ}$, $t_{2}=5$ per.), (b) No. $2\left(Q=0.88 \mathrm{~kJ}, t_{2}=5\right.$ per. $)$, and (c) No. $6\left(Q=1.20 \mathrm{~kJ}, t_{2}=5\right.$ per. $)$.

discontinuities, such as a void, porosity, and lack of fusion. The occurrence of expulsions is particularly undesirable when aluminium is welded because its direct effect is a total reduction in joint strength of 10-30\% [16]. The minimum weld nugget diameter calculated according to Eq. (1) was determined for $d_{\mathrm{w}}>4.0 \mathrm{~mm}$ for selected material thicknesses. From the results obtained it can be stated that with a shorter welding time of $t_{1}=3$ per. $(0.06 \mathrm{~s})$ conditions that would ensure the production of a non-expulsion joint with the minimum weld nugget diameter were not achieved (Table 6).

The optimization of welding current at a welding time of $t_{2}=5$ per. $(0.10 \mathrm{~s})$ is documented in Table 6 and Fig. 3. When a current of $I<9.5 \mathrm{kA}$ was used, the sample was broken on the sheets' interface during the peel test, Fig. 3a. With the use of $I=9.68 \mathrm{kA}$ current (Table 6, Fig. 3b), the joint was broken by the peel test on the side of the aluminium sheet. A further increase of the current up to $I=11.3 \mathrm{kA}$ caused an increase in the diameter of the weld nuggets from $d=3.1 \mathrm{~mm}$ to $d=4.8 \mathrm{~mm}$. The minimum weld nugget diameter determined by the calculation at $d_{\min }=4.0 \mathrm{~mm}$ al- 


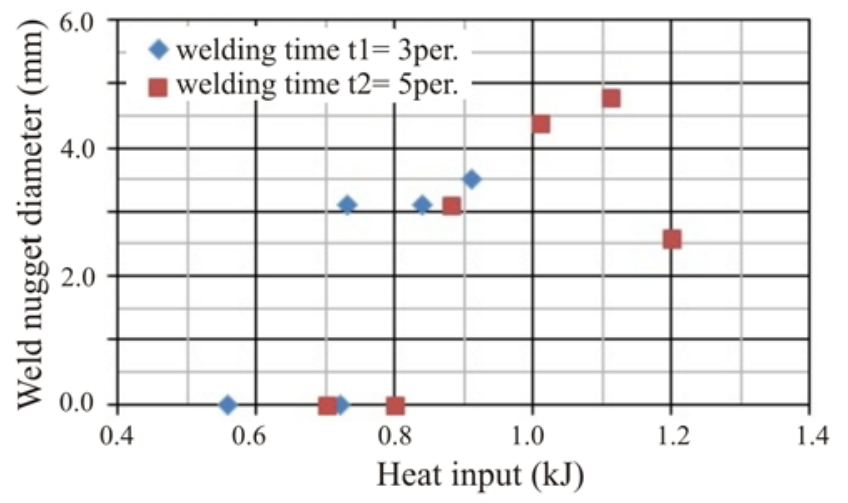

Fig. 4. The relationship between the diameter of the weld nuggets $(\varnothing d)$ and welding heat input.

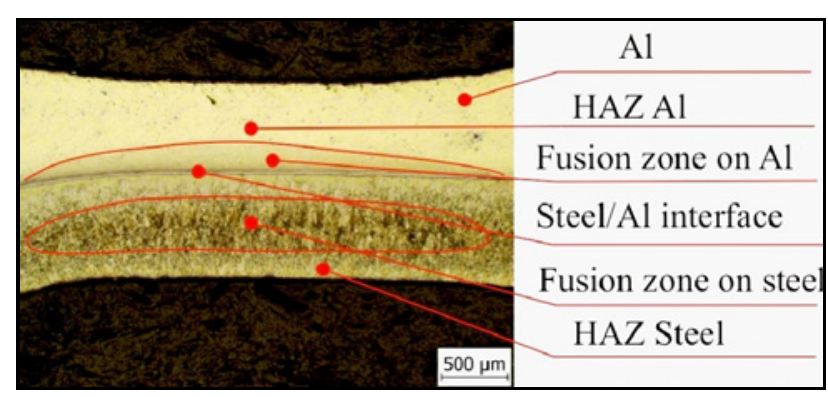

Fig. 5. The macrostructure of sample No. 2 (see Table 6).

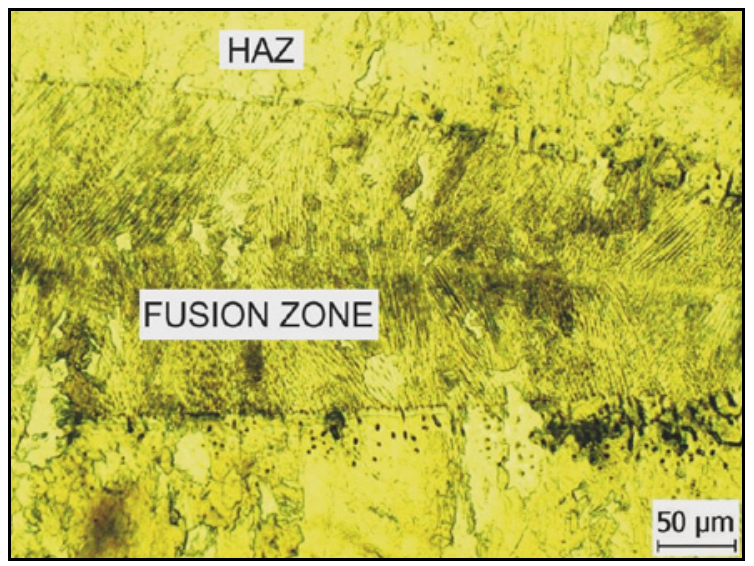

Fig. 6. Structure of weld nugget in steel sheet (etched).

ready complies with the $I=10.4 \mathrm{kA}$ welding current. A further increase of the welding current above $12 \mathrm{kA}$ caused expulsion of liquid metal out of the welded sheets' interface (Fig. 3c).

The deficiency of the material in the weld nugget caused by expulsion was reflected in the reduction of its diameter below the minimum value (Table 6).

Effect of heat input $Q$ on weld nugget diameter using welding time $t_{1}=3$ per. $(0.06 \mathrm{~s})$ and $t_{2}=5$ per.
$(0.10 \mathrm{~s})$ is documented in Fig. 4 . It can be seen that to produce symmetrical weld nuggets, a shorter welding time $t_{1}$ requires a lower power input $Q_{1}=0.77 \mathrm{~kJ}$ than with a longer welding time $t_{2}$ where the symmetrical nugget is formed up to $Q_{2}=0.88 \mathrm{~kJ}$. The difference in heat input is associated with a higher heat output over a longer welding time. In this case, however, the hard welding mode - using shorter time $t_{1}$ and greater current $\left(I_{\max }=13.7 \mathrm{kA}\right)$ did not ensure the creation of symmetrical weld nuggets with a diameter greater than $4 \mathrm{~mm}$ without expulsion. Satisfactory conditions were reached by the mild welding mode using a longer heating time $t_{2}$ and a lower current $(I=11.3 \mathrm{kA})$. Using the above-mentioned parameters $t_{2}$ and $I_{2}$, the weld nuggets of the required diameter $\left(d_{\min }>4.0 \mathrm{~mm}\right)$ were made without any voids after expulsion. A further increase in the welding current to $I=12 \mathrm{kA}\left(Q_{2}=1.2 \mathrm{kA}\right)$ led to expulsion of liquid metal from the weld nugget and a reduction in its diameter (Fig. 4).

2 . The cross-section of the joint between the galvanized steel sheet and the aluminium sheet is illustrated in Fig. 5. It is evident from the macrostructure of the joint that during the heating process both joined materials were melted. As can be seen from the illustrated cross-section (Fig. 5), the plastic deformation of the joined materials during resistance spot welding is found on the aluminium sheet. The nugget-shaped fusion area on steel sheet was localized centrally (to the centre of the sheet thickness). The nugget height was in all cases less than the thickness of the steel sheet used.

Figure 6 illustrates in detail the interface between the structure of the fusion zone of the steel sheet and the heat-affected zone (HAZ-steel). The dimensions of the nuggets depend on the welding parameters used (Table 6).

The aluminium sheet was melted only in the zone adjacent to the joined material interface (Fig. 5). The height and width of the melted area were again proportional to the welding parameter used and the heat input to the weld. The metal structure of the fusion zone and the HAZ-Al structure are shown in Fig. 7. The transition area between the joined materials was bounded by the HAZ-steel zone and the fusion zone of the aluminium sheet (Fig. 5). It is clear from the character of the pronounced transition area that the joint between the various materials selected using resistance spot welding has the character of the brazed joint - the braze in this case was replaced by the molten metal of the aluminium sheet.

Papers published to date, evaluating the properties of the various joints between galvanized steel and aluminium sheets, have shown that the thickness and structure of the transition zone consisting predominantly of intermetallic compounds of the $\mathrm{Al}_{x} \mathrm{Fe}_{y}$ type have a major influence on the mechanical properties of 


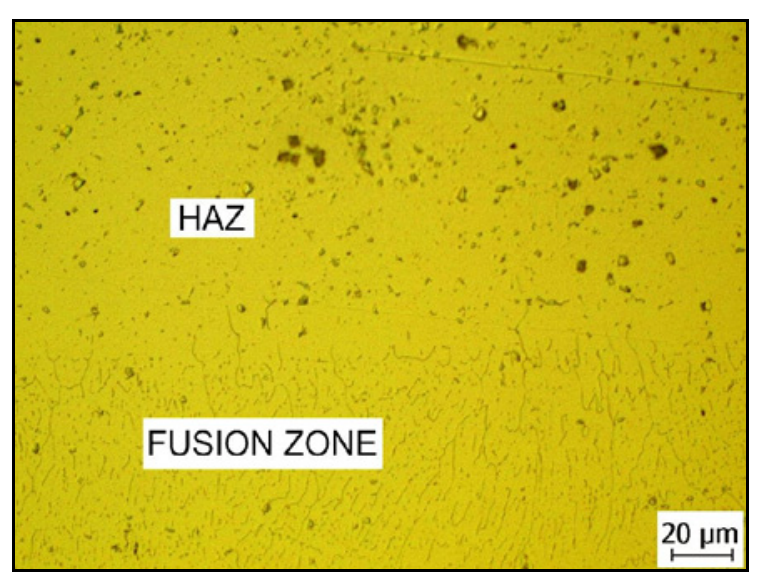

Fig. 7. The difference in structure between the fusion zone and the HAZ on the aluminium part (etched).

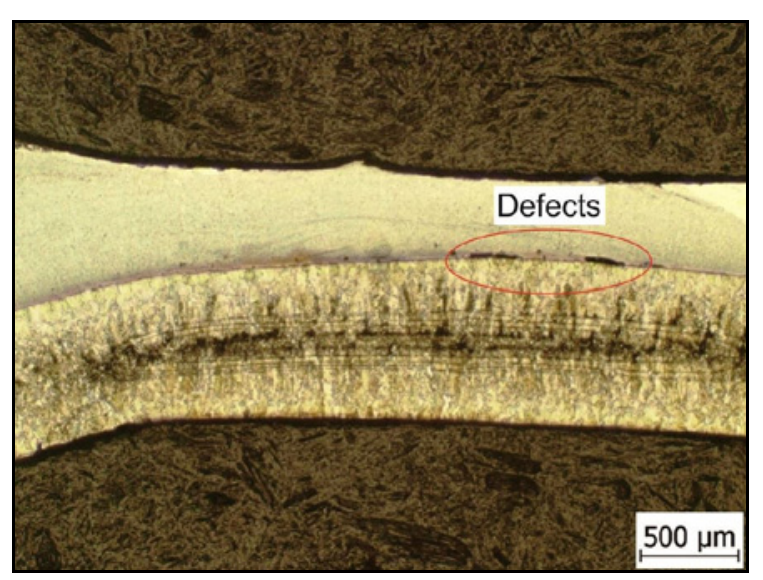

Fig. 8. The macrostructure of sample No. 6 (see Table 6).

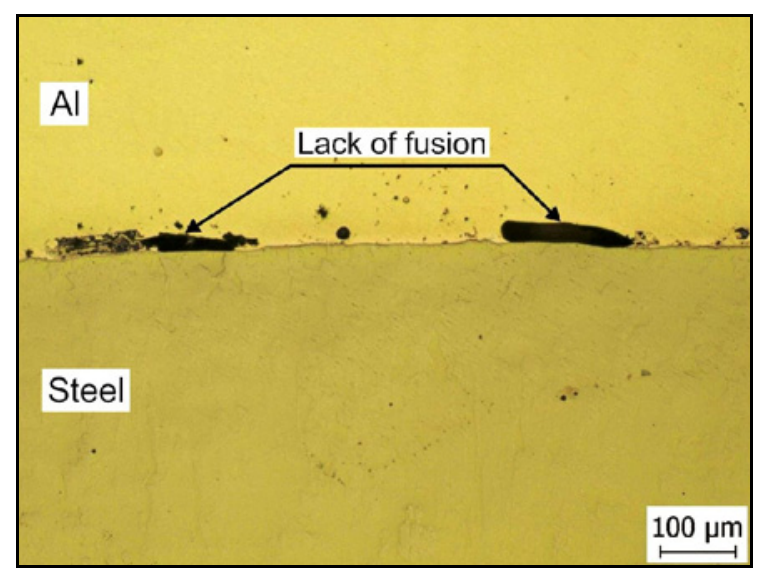

Fig. 9. Lacks of fusion - sample No. 6, polished (see Table 6 ).

the joints $[7,8,17,18]$. Of course, they are also affected by the occurrence of defects at the interface between

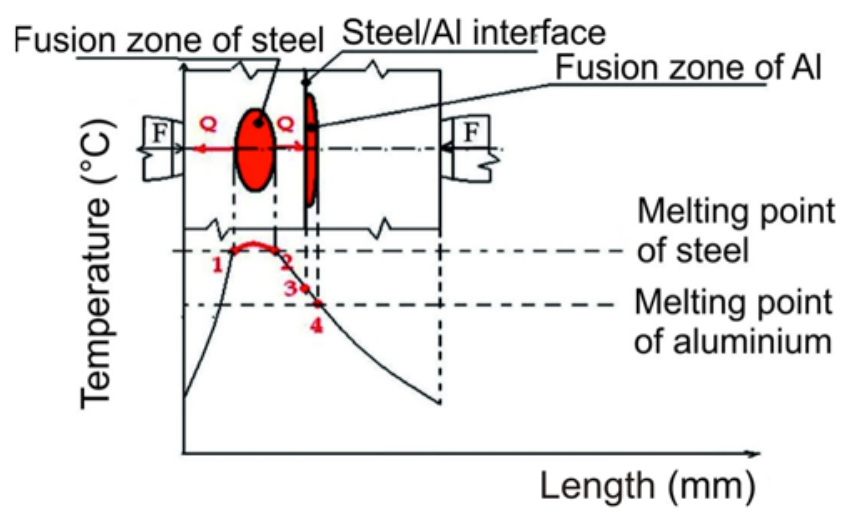

Fig. 10. Maximum temperature distribution across the joint.

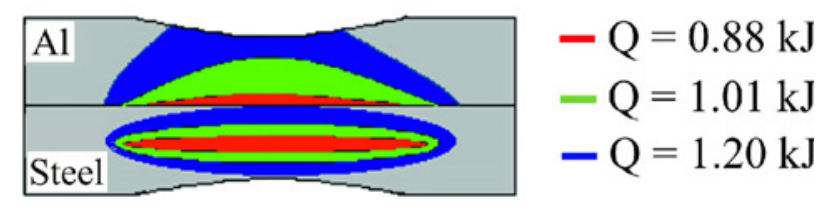

Fig. 11. Melted areas of welded materials when using the welding time for 5 periods.

sheets, such as pores and lack of fusion (Figs. 8, 9).

From the analysis of the macrostructure of the cross sections of the joints, a model of the maximum temperature distribution at the joint point during resistance heating was designed (Fig. 10). It can be assumed that during the electric current flow between the electrodes (due to the significantly different electrical conductivity of the materials used, Table 3), the highest Joule heat concentrations occur in the middle part of the steel sheet. If the temperature exceeds the melting point of steel (for unalloyed steel $1537^{\circ} \mathrm{C}$ ), a certain amount of molten metal is formed in the shape of a nugget.

In this area, the heat generated during the connection is intensely transferred towards the water-cooled electrodes. The temperature gradient then causes the maximum temperature to exceed the melting point of the aluminium $\left(660^{\circ} \mathrm{C}\right)$ at the steel/aluminium sheets' interface. The melting range of the aluminium material at the interface of the joined materials then depends on the heat input to the weld (welding parameters), Figs. 11 and 12, and the heat dissipation intensity towards the electrodes. Since the maximum temperature at the interface of the joined materials did not exceed the melting temperature of the unalloyed steel, the joint was formed by wetting the surface of the galvanized steel sheet with molten aluminium material. From the resulting weld properties, it is important to know the structure of the aluminium/steel transition zone and the adjacent regions 


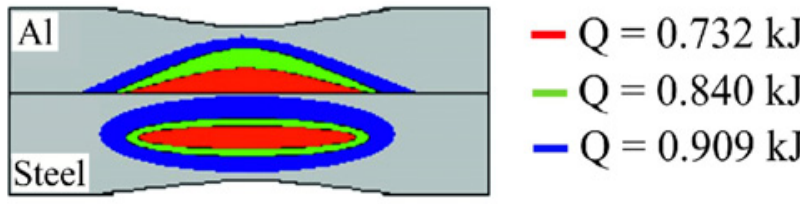

Fig. 12. Melted areas of welded materials when using the welding time for 3 periods.

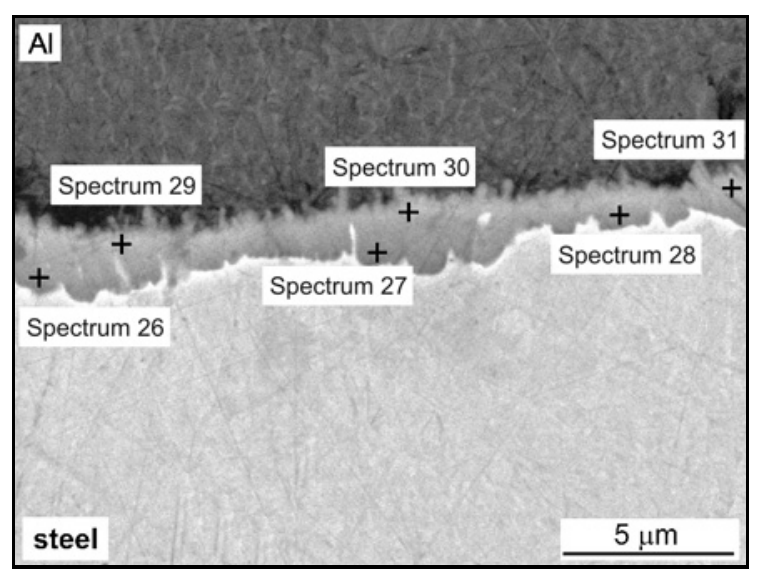

Fig. 13. SEM of the transition zone of the joint No. 7 .

of the galvanized, as well as the aluminium sheet. On the side of the steel sheet, the base material was not melted. Grains in HAZ have therefore been recrystallized in polyhedral form. Due to the resistance welding time/temperature cycle, which is characterized by high cooling rates, there is no reason to predict any grain thickening further than the nugget boundary formed in the central part of the steel sheet (Figs. 5, 8). On the side of the aluminium sheet, the joining material was melted on the metal sheets interface. The structure, therefore, has cast morphology (Fig. 7).

A more detailed analysis of the aluminium/steel transition region is shown in Fig. 13 and Table 7. A scanning electron microscope with an EDS analyzer was used for the analyses. By spectral analysis, it can be stated that the structure of the transition (reaction) region consists of an intermetallic compound $\mathrm{Al}_{x} \mathrm{Fe}_{y}$ type (Figs. 14, 15). No zinc from the steel sheet surface was identified in the reaction zone, which is consistent with the results published in the paper [19].

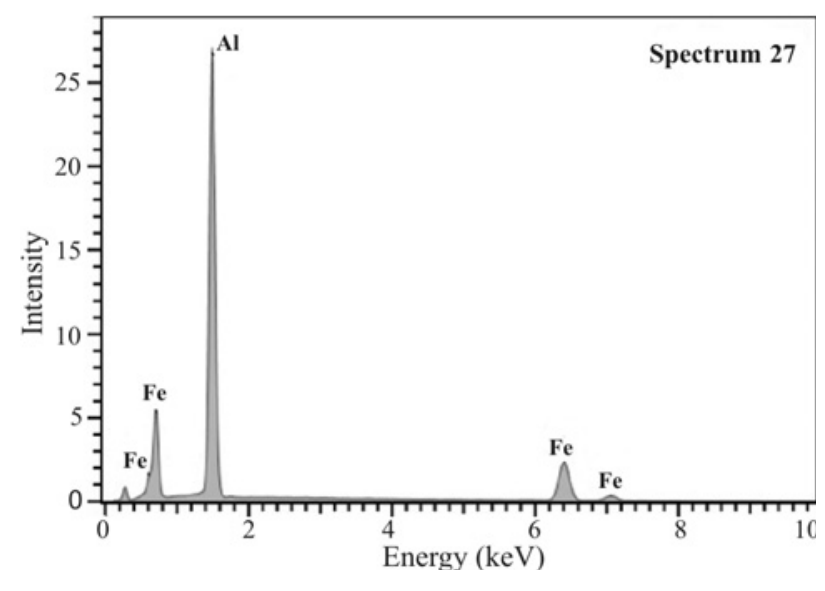

Fig. 14. EDS spectra of reaction product $\mathrm{Al}_{3} \mathrm{Fe}$.

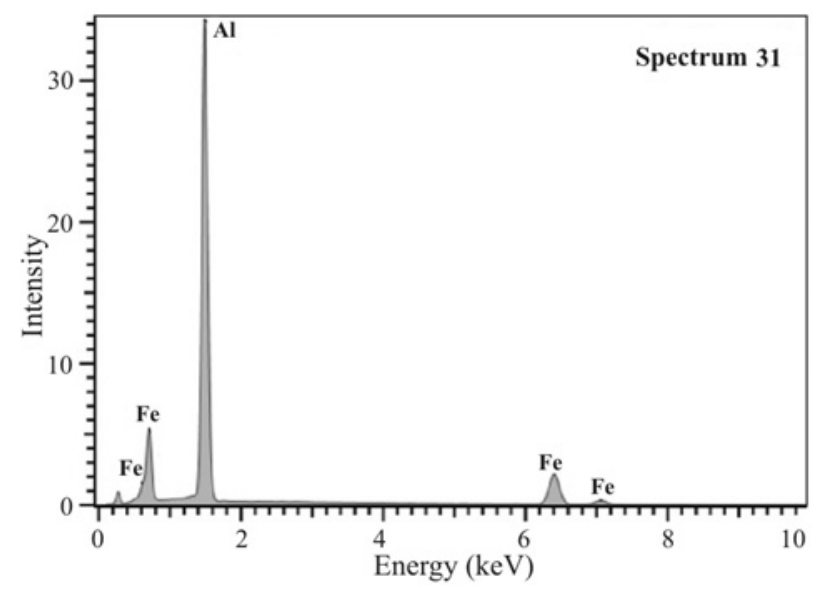

Fig. 15. EDS spectra of reaction product $\mathrm{Al}_{5} \mathrm{Fe}$.

A transition zone, consisting predominantly of intermetallic compounds of the $\mathrm{Al}_{x} \mathrm{Fe}_{y}$ type, was analysed in detail, for example, in [8]. The SEM of the reaction zone of sample 7 (see Table 6) is shown in Fig. 13. EDS analysis of selected points is in Table 7. Using the optimized welding parameters (Table 6), the maximum thickness of the reaction zone in the joint was found to be $h=3.9 \mu \mathrm{m}$. Spectral analysis (Figs. 14, 15) shows that its structure is not affected by the $\mathrm{Zn}$ coating on the steel sheet. Zinc, due to its low melting temperature $\left(T=420^{\circ} \mathrm{C}\right)$, is extruded to the edge of the weld nugget during the process. Thus, the reaction region is formed by intermetallic compounds of

Table 7. EDS analysis of selected cross-section locations (see Fig. 13)

\begin{tabular}{lcccccc}
\hline Elements & Spec. 26 & Spec. 27 & Spec. 28 & Spec. 29 & Spec. 30 & Spec. 31 \\
\hline Al (at.\%) & 72.01 & $\mathbf{7 3 . 4 3}$ & 70.09 & 77.47 & 77.52 & $\mathbf{7 8 . 4 4}$ \\
Fe (at.\%) & 27.99 & $\mathbf{2 6 . 5 7}$ & 29.91 & 22.53 & 22.48 & $\mathbf{2 1 . 5 6}$ \\
\hline
\end{tabular}


the $\mathrm{Al}_{x} \mathrm{Fe}_{y}$ type. Based on the measured data of the $\mathrm{Al}$ and $\mathrm{Fe}$ content and published data [19], it can be stated that on the face of the aluminium sheet, the reaction zone consists of $\mathrm{Al}_{3} \mathrm{Fe}$ grains with needle-like morphology and $\mathrm{Al}_{5} \mathrm{Fe}_{2}$ with tongue-like morphology. The structure of the studied transition zone between aluminium and steel and its thickness corresponds to the data published in the papers $[17,18]$.

\section{Conclusions}

Galvanized steel sheet type: HX 220 BD-Z100 MBO, of thickness $h_{1}=0.8 \mathrm{~mm}$ and EN AW 1050A aluminium sheet of thickness $h_{2}=1.0 \mathrm{~mm}$ were used for the production of lap joints by resistance spot welding. The results can be summarized as follows:

1. As a criterion for optimizing welding parameters, the minimum diameter of the welding nugget $d_{\text {min }}>4.0 \mathrm{~mm}$ without expulsion was chosen. With a shorter welding time of $t_{1}=3$ per. $(0.06 \mathrm{~s})$, conditions (welding current size I) were not achieved to ensure the production of a non-expulsion joint with a minimum nugget diameter. This condition was met at a longer welding time of $t_{2}=5$ per. $(0.10 \mathrm{~s})$ and a welding current of $I=10.4 \mathrm{kA}$. In this case, such a hard welding mode - shorter time $t_{1}$ and greater current $\left(I_{\max }=13.7 \mathrm{kA}\right)-$ did not ensure the creation of a symmetrical weld nugget with a diameter greater than $4 \mathrm{~mm}$ without a fusion metal expulsion. Appropriate conditions were achieved by the soft welding mode - by using a longer heating time of $t_{2}$ and less current $I$.

2. When analysing the structure of the welding joint on transverse sections, it was found that the nugget-shaped melting area on the steel sheet was located centrally (towards the centre of the sheet thickness). The nugget height was in all cases less than the thickness of the steel material used. Melting of the aluminium sheet only occurred in the zone adjacent to the aluminium/steel sheets' interface. The height and width of the melted area were again proportional to the welding parameter used and the heat input to the weld. It is clear from the character of the pronounced transition area that the joint between the selected dissimilar materials using the resistance spot welding process has the character of a brazed joint, with the molten aluminium functioning as solder.

3 . The transition (reaction area) between the galvanized steel and the aluminium sheet of thickness up to $3.9 \mu \mathrm{m}$ was formed by intermetallic compounds of the $\mathrm{Al}_{x} \mathrm{Fe}_{y}$ type. Based on the measured data of the concentration of $\mathrm{Al}$ and $\mathrm{Fe}$ elements, and the published findings, it can be stated that on the face of the aluminium sheet, the reaction zone consists of $\mathrm{Al}_{3} \mathrm{Fe}$ needle-like morphology grains and $\mathrm{Al}_{5} \mathrm{Fe}_{2}$ grains with a tongue-like morphology.

\section{Acknowledgement}

The results given in this paper were obtained as part of VEGA 1/0394/16 research project.

\section{References}

[1] Atabaki, M. M., Nikodinovski, M., Chenier, P., Ma, J., Harooni, M., Kovacevic, R.: J. Manuf. Sci. Prod., 14, 2014, p. 59. doi:10.1515/jmsp-2014-0007

[2] Schubert, E., Klassen, M., Zerner, I., Walz, C., Sepold, G.: J. Mater. Process. Technol., 115, 2001, p. 2. doi:10.1016/S0924-0136(01)00756-7

[3] Pardal, G., Meco, S., Ganguly, S., Williams, S., Prangnell, P.: Int. J. Adv. Manuf. Technol., 73, 2014, p. 365. doi:10.1007/s00170-014-5802-y

[4] Meško, J., Zrak, A., Mulczyk, K., Tofil, S.: Manuf. Technol.: Journal for Science, Research and Production, 14, 2014, p. 355.

[5] Perk, H. J., Rhee, S., Kang, M. J., Kim, D. C.: Mater. Trans., 50, 2009, p. 2314. doi:10.2320/matertrans.M2009105

[6] Gene, M.: The Welding of Aluminium and its Alloys. Cambridge, Woodhead Publishing Ltd. 2002.

[7] Qiu, R., Iwamoto, C., Satonaka, S.: Mater. Charact., 60, 2009, p. 156. doi:10.1016/j.matchar.2008.07.005

[8] Agudo, L., Eyidi, D., Schmaranzer, Ch. H., Arenholz, E., Jank, N., Bruckner, J., Pyzalla, A. R.: J. Mat. Sci., 42, 2007, p. 4205. doi:10.1007/s10853-006-0644-0

[9] Haidara, F., Record, M. C., Duployer, B., Mangelinck, D.: Intermetallics, 23, 2012, p. 143. doi:10.1016/j.intermet.2011.11.017

[10] Shabadi, R., Suery, M., Deschamps, A.: Metall. Mater. Charact. A, 44, 2013, p. 2672. doi:10.1007/s11661-012-1605-7

[11] Aluminium Material Data Sheet. http://www.fillistahl.at/files/datenblatt_1050_ bleche.pdf

[12] EN AW-1050A: Properties of Aluminium Alloys. http://addaxbg.eu//alloys.Php?route=alloy\&lang= $\underline{\text { en }}$

[13] Thermal Conductivity of Metals. http://www.engineeringtoolbox.com/thermalconductivity-metals-d_858.html

[14] Menu Metals Properties. http://www.tibtech.com/conductivity.php

[15] Sale of Aluminium, Bronze and their Alloys. http://www.hlinik.sk/en/products/aluminum-sheet/ EN-AW-1050A

[16] Zhang, H., Senkara, J.: Resistance Welding. Fundamentals and Applications. Boca Raton, CRC Press 2012.

[17] Qiu, R., Iwamoto, C., Satonaka, S.: J. Mater. Process. Technol., 209, 2009, p. 4186. doi:10.1016/j.jmatprotec.2008.11.003

[18] Qiu, R., Satonaka, S., Iwamoto, C.: Mater. Des., 30, 2009, p. 3686. doi:10.1016/j.matdes.2009.02.012

[19] Penner, P., Liu, L., Gerlich, A., Zhou, Y.: Weld. J., 93, 2014, p. 225. 